Comics Studies 



\section{Comics Studies}

A Guidebook

EDITED BY CHARLES HATFIELD AND BART BEATY

id

Rutgers University Press

New Brunswick, Camden, and Newark, New Jersey, and London 
Names: Hatfield, Charles, 1965- editor. | Beaty, Bart, editor.

Title: Comics studies : a guidebook / edited by Charles Hatfield and Bart Beaty.

Description: New Brunswick, New Jersey : Rutgers University Press, 2020. | Includes bibliographical references and index.

Identifiers: LCCN 2019050055 | ISBN 978081359142I (hardback) | ISBN 9780813591414 (paperback) | ISBN 9780813591438 (epub) | ISBN 9780813591445 (mobi)| ISBN 9780813591452 (pdf) Subjects: LCSH: Comic books, strips, etc.-History and criticism. Classification: LCC PN6710.C6664 2020| DDC 741.5072-dc23 LC record available at https://lccn.loc.gov/2019050055

A British Cataloging-in-Publication record for this book is available from the British Library.

This collection copyright ( 2020 by Rutgers, The State University of New Jersey Individual chapters copyright (C) 2020 in the names of their authors All rights reserved No part of this book may be reproduced or utilized in any form or by any means, electronic or mechanical, or by any information storage and retrieval system, without written permission from the publisher. Please contact Rutgers University Press, 106 Somerset Street, New Brunswick, NJ 0890I. The only exception to this prohibition is "fair use" as defined by U.S. copyright law.

(2) The paper used in this publication meets the requirements of the American National Standard for Information Sciences-Permanence of Paper for Printed Library Materials, ANSI Z39.48-1992.

www.rutgersuniversitypress.org

Manufactured in the United States of America 
In memory of

Don Ault and Tom Spurgeon, mentors and great soulsand to the comics scholars

of the future 
